\title{
The Foundation of Knowledge
}

\author{
Louay Safi \\ Herndon, VA: The International Institute of Islamic \\ Thought, 2014. 214 pages.
}

The interlinked nature or interconnected dimension of al-'ulüm al-Islāmīyah (Islamic sciences), which comprise such areas as syntax, morphology, semantics, linguistic philosophy, logic, legal theory and jurisprudence, prosody, rhetoric, exegesis, hadith, and one or two related others, has arguably remained an unsung story in contemporary scholarship. Such an interesting feature of Islamic traditional knowledge should not be obscured, especially in view of the centrality of such areas of learning to ușül al-fiqh (the science of Islamic jurisprudence), which cannot be a functional whole if any of them are absent. The work under review, The Foundation of Knowledge, has done creditably well by not only underscoring such interconnectedness, but also by analyzing (somewhat comparatively) the classical Muslim and modern western methods with a view to exposing the inadequacy of established methods before attempting a creative synthesis of the two.

Despite the rigor involved in his analysis, however, Safi arguably starts on a somewhat contradictory note by claiming that "the synthesis offered ... is not concerned with bringing harmony between the two traditions, but aspires to integrate the knowledge received from revelation with the one gained from human experience" (p. 14). For a book addressing the foundation of knowledge, which is essentially grounded in philosophy - especially its sub-area of logic - one wonders how a "synthesis" can be associated with "integration" but divorced from "harmony." Yet the book's objective is unmistakable in Safi's emphasis on "the need to guard against distortions caused by the specific values and presuppositions espoused by individual scholars, as well as the importance of bringing critical analysis to scholarly research underscoring the need to critically engage both modern and traditional scholarship" (p. 11).

The work is divided into four parts. In Part I, "The Inadequacy of the Established Methods," the author traces modern thought to the struggle for supremacy between the pre-modern religious tradition and the Enlightenment, which was a philosophical tradition. He argues (1) that the modern tradition's systematic nature culminated in the development of scientific theories and research methods in various areas of social sciences, but failed to record such progress in its attempt to explain value systems through the aid of such theories and methods; (2) that this limitation of empiricism and positivism stimulated 
the curiosity of postmodern writers, whose denial of the possibility of pursuing truth amounts to "placing rationalism on equal footing with irrationalism, and drawing no distinction between morality and immorality" (p. 18); and (3) that Islamic thought advanced long before modern western rationalism and long ago strove "to limit human rationality to the examination of empirical reality and the analysis of sensory data" (p. 18).

It is interesting to note in this chapter that Islamic thought has always undermined human reason, as evident in al-Ghazali's Tahäfut-al-Falāsifah and works by other Muslim thinkers. Safi shows the inadequacy of empiricist methods (pp. 18-20), the insufficiency of anchoring knowledge in pure reason (pp. 20-22), and the deficiency of limiting reason to empirical truth (pp. 2225). Making a case for what he calls "transcendental rationality," which he describes as "an alternative approach to knowledge and truth, whereby reason and received texts do not stand to negate each other, and neither can claim final authority" (p. 27), Safi claims to have "attributed the inadequacy of traditional methods to three factors, namely, being exclusively legalistic, being overtly linguistic, and being excessively atomistic" (p. 28). However, while even a cursory glance can reveal that the first two claims are correct, a meticulous look can hardly see where the author alludes to the "excessively atomistic nature" of the traditional methods anywhere in the chapter.

Part II, "Classical Muslim Methods," comprises chapters 2, 3, and 4. Chapter 2 discusses textual analysis in connection with the rules of direct inference. A careful look reveals that it may aptly be described as an analysis of al-Imam al-Shafi'i's seminal Al-Risālah. The author identifies the text (nașs) and deductions therefrom (istinbāt) as the two sources of meaning featured in Al-Risālah. Similarly, he identifies bayān (clarification) and qiyās (analogy) as the titles under which al-Shafi' $i$ discussed textual interference. The author equally identifies $i k h t i l a \bar{f}$ (disagreement) and $i j m \bar{a}$ ' (consensus) as al-Shafi'i's two main classifications of the knowledge produced through bayān and qiyās. He asserts that al-Shafi'i's intellectual exploits in uṣül-al-fiqh are applicable to other fields of scientific research and illustrates this by claiming that bayān, which later developed into 'ilm al-ma 'ānī (semantics), was employed in such areas as tafsìr al-Qur'ān (Qur'an interpretation) and al-naqd al-adabì (literary criticism). Safi seems to be at his best in this chapter, where he analyzes the essential procedures used by classical Muslim scholars under the rubric ușūl al-fiqh.

In chapter 3, the author proceeds to the rules of systematic inference, which address logical analysis as pursued by Muslim scholars in their interpretation of reality. He relies on credible Islamic sources in his attempt to define science 
(ta'rîf al-'ilm), articulate the place of logic (mantiq) among early Muslim philosophers and dialecticians who divided its study into two parts, namely, the study of tasawwur (concept) and of tașdīq (validation), and then sub-divided the latter into the study of qadiyah (proposition) and qiyās (syllogism). However, Safi points out that this categorization is not universally embraced, alluding to the difference between Ibn Sina's notion of tașdīq, which is merely associated with qiyass, and al-Ghazali's conception thereof, which is associated with qadiyah. The numerous examples provided by the author to demystify the intricacies of logical reasoning constitute a remarkable strength of this chapter.

Chapter 4 reads more like an extension of chapter 3 in several respects. The major difference is that whereas the former focuses on logic, the latter concerns itself with metaphysics, in connection with science. The author exposes the limitation of rational arguments, reproduces the philosophers' argument (pp. 99-101) as presented by al-Ghazali in his Tahäfut al-Falāsifah, and analyzes his objection to it, rather systematically and extensively (pp. 102-08). Safi complements his analysis by engaging with Ibn Rushd's refutation of alGhazali and other Muslim mutakallimūn who employed an admixture of the typology of argument used in the study of religion and for understanding nature. Ultimately, the chapter exposes how the mutakallimün successfully employed Greek logic to deflate the project of Muslim philosophers and provides an impressive account on how notable Muslim scholars like Ibn Taymiyyah and Ibn Khaldun followed al-Ghazali in rejecting Greek philosophy. The chapter shows that classical Islamic methods have a great potential for re-establishing an effective methodology for social research, but may have little to offer action analysis and inference, which is why carefully examined aspects of modern western scholarship may be embraced for integration.

Part III, "Modern Western Methods," contains two chapters (5 and 6). In chapter 5, Safi relates how western thinkers embraced Muslim misgivings about Greek logic around the fifteenth century. According to him, Francis Bacon (1561-1626) had already tried to formulate an alternative methodology for western scholarship. The author explains Bacon's two sets of principles as sine qua non to the intellect's understanding of reality: (1) intimate or inherent and (2) external. He critically analyzes Bacon's argument that external principles cannot be trusted because they are subject to error and distortion (pp. 127-30), alongside the five methods of induction expounded by John Stuart Mill (1806-73). While engaging critically with John Locke's (1632-1704) An Essay Concerning Human Understanding (1689), he argues that the human mind is blank at birth and only derives its ideas from experience, which is the foundation of knowledge. 
Safi regards Locke as one of the very few western thinkers to have confronted the question of revelation in a rather unequivocal manner. The author obviously is at his best when he painstakingly demonstrates how David Hume's (1711-76) argument causes a crisis, which was later solved by Immanual Kant (1724-1804). According to Safi, the question of whether or not divine revelation is a credible source of knowledge can only be answered by "intellectually competent persons who have had a profound and meaningful encounter with claims of revelation in both totality and specificity" (p. 151).

Chapter 6 further pursues the modern western methods and focuses on the naturalistic methods and the peculiarity of social studies. Thus Emile Durkheim (1858-1917) and Karl Popper (1902-94) receive adequate attention. The author highlights Durkheim's principal rules for studying social phenomena, namely, that the sociologist must disregard all preconceptions, that only phenomena definable by empirical features can be the subject of scientific research, and that the sociologist exclude all data that originate from the manifestation of social phenomena in individual consciousness (pp. 153-58). He also underscores the five characteristics of Popper's philosophical foundation of knowledge, namely, conjecture, evaluation for reliability, empirical testability, tentative verifiability, and consistency with subsequent scientific discoveries (pp. 159-68). The deficiency of the modern western methods, which are incapable of transcending their immediate environment or physical surroundings, as exposed by Popper, constitutes a good rationale, in terms of the author's argument, in favor of the need to embrace a transcendental reality for a meaningful understanding of nature.

In Part IV, the author describes his proposed methodology as one with the potential to fulfill a dual role of both analyzing complicated social phenomena and attempting an informed and systematic derivation of principles from revelatory sources. He attributes the exclusion of transcendental knowledge from modern western scholarship as a product of equating revelatory sources with ungrounded metaphysics, which was accorded the status of "a rival body of knowledge, contradistinguished to the body of knowledge deemed to be true by reason" (p. 173). In analyzing the metaphysical presuppositions of empirical knowledge, the author declares that scientific activities are impossible without transcendental presuppositions.

He ventures to correct a possible misconception that the modern western exclusion of revelation from the realm of science is a product of the denial that it makes assertions about the nature of reality. Conversely, he insists, this exclusion is based on the claim that only empirical reality can be ascertained. Safi's proposed unified methodological model, it should be noted, is charac- 
terized by five interconnected procedures, namely, "analysis of text/phenomenon into its basic components, grouping of similar statements/actions under one category, identification of the rules that unify various categories, identification of general rules and purposes that govern interaction of various categories, and systematization of the body of rules obtained through the previous procedures" (p. 193).

This valuable book presents a sophisticated, comparative, contrasting, and synthetic analysis of traditional Islamic scholarship and modern western Islamic sciences. The author's scholarly insights make it a rewarding read. Scholars in the Islamic sciences and western-oriented disciplines would find it inestimable, despite the numerous misprints and few linguistic errors: that that (that) p. 18; by little and little (little by little) p. 21; bedrock foundation (superfluous: simply bedrock or foundation) p. 22; occupy (occupies) p. 29; the study of methodology (also superfluous: methodology or the study of methods) p. 30; ikhtilāfistinbāt (istinbāt) p. 36). The meaningful endnotes, rich bibliography, and virtually all-encompassing index are among this book's numerous strengths.

Saheed Ahmad Rufai Dean, Faculty of Education Sokoto State University, Nigeria ahmadrufaisaheednew@yahoo.com 